\title{
GENDER SENSITIVE AND GENDER NEUTRAL LANGUAGE: THE WORD-WORLD NEXUS AND ITS FLUCTUATIONS
}

\begin{abstract}
The article focuses on the relationship between language and gender. It explores the ways in which the link between them is reflected in and reflects the socio-political dynamics. It delineates the thematic framework for the constructive debate, rather than proposing solutions for the social unease. The historical perspective brings to awareness the evolution of diverse occurrences of feminism and how they have fashioned the language through which the contested social realm is expressed. Voices from the social margins nowadays claim the language that embodies antidiscrimination politics and mirrors their identity. Transgender activists have raised the question of gender neutral language. Simultaneously, similar demands come from a different standpoint. How is one to understand those points of 'convergence'? Confronted with such a complex situation, one wonders whether diversified discourse reflects atomized society. One may also ask if it spurs the dispersal of the social. By contrast, one would like to know if it perhaps reverberates with and inspires the blossoming of pluralist culture and linguistic playfulness it can ensure. One wonders how we can both exercise and discuss antidiscrimination politics, and avoid the bewilder-
\end{abstract}

stefanovic_tamara85@yahoo.com

aidnimspasic@yahoo.com

This paper was submitted on May $13^{\text {th }}, 2019$ and accepted for publication at the meeting of the Editorial Board held on September $16^{\text {th }}, 2019$. 
ment that the fluctuations of the world-word nexus sometimes cause. Moreover, the question of immense importance is how we can avoid hypocrisy while trying to harmonize discourse and the social sphere. The overarching question seems to be how we can generate a sound community of human beings in which language is the means of vibrant communication.

KEYWORDS: language; gender; sensitive; neutral; politics; antidiscrimination; power.

\section{THE ONSET OF FEMINISM}

The focus of the article is the language-gender nexus and its mutual relationship with the socio-political and the everyday. The historical overview delineates the modifications that have occurred both in the extralinguistic and in language. The article explores and looks at the issues pertinent to the peculiarities of the situation and the thematic, yet refrains from offering definitive solutions. Rather, it provides the framework for thinking critically about the issues that figure prominently in contemporary socio-political spheres in the hope that it can inspire a stimulating dialogue and ensure sensible human communication where pluralism and diversity enable playfulness and liberties instead of collision and oppression.

Feminist endeavors have ensured rights for women and gender sensitive language. Gender politics has invigorated the inclusion of the discriminated. The official accounts of the struggle for women's rights originate in the early twentieth century women activists' demands for the right to vote, education, and work. Those were the major nodes of deprivation and the main bases of discrimination. The fruits of that struggle are now available to us. The movement known as the first wave feminism also eludes classification, since at that time there was no word that could encapsulate the agenda and/or ideology. There was merely the awareness and energy channeled through recalcitrance and disobedience mobilized under the leadership of the Pankhursts, and spread and galvanized by the acolytes-fellow rebels, both contemporaries and of the generations to come.

The battle for suffrage brought to the world a new way of describing the social sphere. The word suffragette was born. According to Online Etymology Dictionary, it entered the English language in 1906. Merriam Webster Dictionary states that it was first used in 1902 in the meaning "a woman who advocates suffrage for women". It was coined to ridicule the revolt against inequity and 
injustice. MacMillan Dictionary informs that the London Daily Mail's journalist Charles E. Hands devised the term intending to attach to it a derogatory note. In those early days of women's liberation, deeds mattered more than words did. However, those brave torchbearers for freedom recognized the potential of language, as well. The women who were pejoratively named suffragettes adopted the title and refashioned it so that it could mean what they meant it to. It has been used in that very meaning ever since.

\section{THE LANGUAGE OF THE INCLUSION OF THE EVERYDAY IN THE POLITICAL}

As the women's rights movement was gaining impetus, it was christened feminism. The fifties and the sixties of the twentieth century ignited the protest that integrated a multitude of the disenfranchised. It was the time when the political élite started being increasingly experienced not as the guardian of the people, but as a threat to peace, stability, and freedom. The mainstream ideology was questioned and profound distrust of the dominant social and political discourse was on the rise. Countercultures began generating alternative cultural vocabularies and rebelling against the authoritarian, militant, and oppressive social and political forces. The voices of the oppressed spoke through protests, art, lifestyles, theory, grassroots propaganda, and lobbying-forms of expression that were mutually compatible, although sometimes stemming from different bases. The Civil Rights Movement spurred the women's rights movement that can be understood as the continuation of the legacy from the early twentieth century and perceived as the second wave feminism.

The Second World War enhanced the sense of the erosion of stability inherited from the post First World War era. The Vietnam War crisis reinforced that perception. Discourse paralleled the atomized social sphere. Specifically, poststructuralist vocabularies that established themselves as vernaculars in their own right relied on the plurality of perspectives. They reject the possibility that any vocabulary can assume the privileged access to the truth. That was a democratic intervention in the realm of language and it reverberated with and enabled the discursively constructed cultural realm. The women's movement in that period accentuated the questions 
of the bodily, reproductive rights, sexual abuse, domestic violence, heteronormativity, patriarchy, unpaid labor, and other demonstrations of supremacy. Feminist, antiracist, anticolonialist, underprivileged, and gay voices started converging under the hub discourse to be recognized as queer. The muted have voiced their presence in the world in gender sensitive language.

\section{THE CONNECTIONS BETWEEN GENDER, CLASS, POPULAR CULTURE, AND POWER}

Discourse was being fashioned in accordance with the belief in the power of language, the power of the human capacity to construct social realities through language, and the power of change. Feminism itself started undergoing certain transformations. The third wave feminism (or the second wave) is associated with the Riot Grr$\mathrm{rl}$ movement. It was an expansion into the realm of popular culture that further challenged male hegemony. It originates in the 1990s Olympia, Washington State, based female punk rebel initiative. Feminist bands like Bikini Kill, Heavens to Betsy, Huggy Bear, and Bratmobile were the response to the male dominance in the underground and mainstream music worlds alike. They followed in the footsteps of the predecessors-the second wave feminism. In addition to popularizing the revolt through music, zines, and freedom of expression, they held gatherings and organized discussions where feminist politics was propagated and from where it was disseminated. The themes included economic inequities, class divide, workplace harassment, sexual restrictions, and the problem of recognition, as evidenced in Hannah (2018). The author Kathleen Hannah was the lead singer of the band Bikini Kill named after the zine whose second issue from the early nineties featured the text of the manifesto. It objects to "racism, able-bodieism, ageism, speciesism, classism, thinism, sexism, anti-semitism and heterosexism" (Hannah, 2018, p. 331). The author, the lead singer of the band Bikini Kill named after the zine, capitalizes on the angry young women's awareness of the socio-political issues, particularly the question of exclusion and the vocabularies reflecting ideology of the oppressed. Their class consciousness was later to evolve into the propaganda advocating women's rights to the leading positions in the corporate sphere. According to the British Library, Riot Grrrl 
still exists (Riot Grrrl, n.d.). Its progeny Riot Girl continues the legacy of the feminist punk rock rebellion.

Women's rights activists have often insisted on the questions pertinent to the domestic sphere, reproductive rights, sexuality, male dominance, and abuse. Women artists have incorporated some of these themes in their expressive modes. Hynde demonstrates the intersection between the private-political nexus and the countercultural. The lead singer of the Pretenders is a mother. She is also a woman in the world of rock ' $n$ ' roll which is still partly run on the principle of male dominance. Yet, she has a voice:

"I'm a mother
Treat me like a mother
You want to suck on my breast
It's no surprise you do
I'm the source and the force
You owe your life to, brother."

(Hynde, 1994)

Stating the identity of the speaker, the song provocatively addresses the theme of the body, invoking both its reproductive and erotic aspects. In the streetwise key, it challenges a male interlocutor with a slight shade of objectification and subjugation to the female life giving force.

\section{THE ROLE OF TECHNOLOGY AND VOICE IN THE EMPOWERMENT OF THE SOCIAL MARGINS}

Although the exact date is debatable, there is a general agreement that the fourth wave feminism (sometimes called the third wave) started around 2012. The gang rape of a young woman in India in December that year spurred the protest and voicing resistance to sexual abuse, sexism, and discrimination. It was mainly channeled through social media. Thus, the movement has embraced technology as a means of empowerment of women who assume the position and take active part in the digital sphere. It is reasonable to argue that we still live in the age of fourth wave feminism. There is a heightened alertness to the awareness of the role and significance of the media in and for the emancipation of women. Looking at youth cultures, Broughton (2012) focuses on education and educa- 
tional institutions with regard to media literacy and different approaches to agency. He criticizes the typical understanding of cultural production that ignores active participation and conscious choices of the young person exposed to media generated content.

Broughton accentuates the need to reshift onto the view that reveals the activity of the individual who not only receives digitally enabled messages, but also engenders and sends them: "Thus youth are not so much pawns of the market or skeptical critics of it; rather, they are spontaneous, creative appropriators of commodities who proceed to edit, revise, repurpose, and redirect what they consume" (Broughton, 2012, p. 249). Broughton remarks different modes of cultural production. Some lean toward the instrumental pattern, whereas some might be subtler, focusing on an indirect impact. Building on Raymond Williams's notion of the structure of feeling, Broughton contends: "This concept suggests how culture can constellate critical affects, representing a symbolic social subjectivity, such that cultural production may then take the form of generative paradigms of identity, interiority, and authenticity. This is a far cry from treating subjects as merely mediators for the production of objective cultural artifacts" (Broughton, 2012, p. 251).

Analogously, women are not defined by the subordination to the dominant cultural paradigm. They can think critically, devise their own expressive modes, and articulate the attitude that resonates with the ideas of agency, consciousness, and revolt against the imposed cultural norms and coercive aspects of dominance based social relations. For example, Grace Savage, London based beat box artist, singer, song writer, and actor assumes the voice in her art through the medium and genre mostly characteristic of male performers. Both the verbal and nonverbal aspects of her work rely on bodily generated sound. The tracks incorporate samples from existing pieces, but there are also composed and performed portions of music not excluding the use of musical instruments. Her art is widely publicized and distributed via social media and her presence in both online and offline communities can be perceived as a form of grassroots activism with a prominent feminist note.

Likewise, Fay Roberts, Cambridge based performance poet, spoken word artist, musician, and MC, who facilitates and hosts poetry slam events in Cambridge and the eclectic literary dialogue at the Edinburgh Festival Fringe, crafts her expression critically approaching the supposed cultural givens. She is an avid observer of patriarchal hegemony, keen critic of coercive normativity, and a 
courageous explorer of the poetic idiom that draws from tradition, yet challenges it through subversive experimental forms. She investigates cross-cultural heritage through the conversation with and among milieus as diverse as Russian folk tales, traditional English literature, and popular culture. As stated in Roberts, she situates her lyric explorations in the symbolic that Russian folklore ascribes to the notion of forest. As a place of wandering, searching, and wondering, it offers a possibility to look at the concept of pursuit of the unknown almost through the lens of pilgrimage. It is labyrinthine space where one finds what one unknowingly knows: "One of the most enduring agents of change is Baba Yaga, she of the iron tooth, the witch-wild hair, the pestle in which she bounds abroad, and her chicken-footed cottage. Say the right rhyme and Baba Yaga's house will turn and let you in..." (Roberts, n.d.).

What magic words can get one to the object of pursuit?

"Little house, little house,

Turn round to see

That there's nobody stopping me,

Least of all me.

With my mistresses gone

And no princes to flee

Little self, please believe me,

I'm perfectly free."

The transformation of the threatening image of the somewhat scary sylvan witchy character into the imagery of safety and inviolability indicates the restorative aspect of the search and the possibility of immunity to coercion.

\section{GENDER INCLUSIVE LANGUAGE BETWEEN NATURE AND CULTURE}

Women's rights have been reflected in language that either echoes or designates social dynamics. The dominant discourse has been reconfigured via the introduction and/or modification of linguistic entities. Simultaneously, it signaled the specificities on which gender related issues and identity politics capitalized. This implied the use of gender sensitive language. The practice included and aimed at engendering linguistic means ensuring that women's rights be 
protected, gender proclivities acknowledged, sexual orientation allowed and legally enabled, social inclusion sustained, and integrity preserved. Adjustment in the lexical, morphological, and syntactic realms were made. For example, in Serbian, the masculine noun 'sekretar' (secretary) has a feminine correlative 'sekretarica'. Some words signifying occupations are unisex, like Serbian noun 'stolar' (carpenter). The feminine version 'stolarka' could be derived, but it is not used very often due to the fact that mostly males occupy those positions. However, Serbian word 'vođa' (leader) does not have a feminine counterpart. There could be distinct gender sensitive lexemes such as 'pisac', a Serbian masculine noun meaning a male writer, whereas 'spisateljica' is a feminine noun that refers to a female writer.

Cultural visibility is discursively demonstrated. Alternatively, the power of language has been manifested through cultural constructs. Both perspectives show the mutually conditioning relationship between the social and language. The fluctuations seem to have gone full circle. Growing demand for gender neutral language is integral to gender politics. The notion of queer incorporates transgender rights. In that context, gender sensitive language can sometimes be politically incorrect. Re-locating language into the gender neutral sphere cannot imply retrieving the discourse from the time before the changes started. What exactly it does imply is yet to be known. Just as the transformation of language reflects cultural climate so is the latter fashioned by the former.

Sometimes, the original motivation mobilizing cultural shifts is obscured by power narratives in disguise. A deeply humane enterprise is normalized by the oppressive, utilitarian mainstream discourse. Gender activists sometimes become oblivious of the genuine reason for rebelling against oppression. The major point of the critique was and should remain that exclusion is premised on the idea of inequality and that it features multiple aspects including class, gender, ethnicity, and race. If the emphasis is put solely on the question of power, it may cause social re-descriptions of a disputable character. This slightly bewildering state of affairs may be reflected both in the normativity that determines politically correct linguistic expression and the absence thereof.

The question that arises from that situation is how to navigate the versatility of vocabularies and express gender awareness linguistically. Part of the answer can be found in Glück describing an encounter with the writing of Kathy Acker-the progenitor of gen- 
der based antiestablishment literature and the emissary of the reconfiguration of dominant discourse. Glück acknowledges Acker's literary contribution to voicing the muted:

"Acker takes revenge on power by displaying what it has done; she speaks truth to power by going where the power differential is greatness, to a community of whores, adolescent girls, artists, and bums, the outcast and disregarded [...] If hegemony defines itself by what it tries to exclude, then the excluded merely need to describe themselves in order to describe hegemony." (Gluck, 2006, p. 48)

This resonates with the point Birns presents in relation to the notion of queer indicating genuine antihegemonic sources:

"Anyone who did not adhere to conventional scenarios of sexuality
or behave in conventional sexual modes could potentially be termed
'queer.' This broadening of the category had some very interesting
ramifications. For instance, it led to many attempts to link queerness
and spirituality as states of being that reached beyond the materiali-
ty of the given world. 'Queer' was as much an attitude of
nonconformity as it was a specific manifestation of sexual identity."
(Birns, 2010, pp. 268-269)

Birns situates the notion of queerness in the decade of the nineties of the twentieth century when Judith Butler's theory inspired or overlapped with the growing versatility of dissident voices. She is the founder of the approach to gender as performativity. In her books Gender Trouble: Feminism and the Subversion of Identity (1990) and Bodies That Matter: On the Discursive Limits of "Sex" (1993), this approach is being articulated as the perspective in its own right. It accentuates gender fluidity, rather than the rigidity of inherent sex and gender manifestations. It offers a possibility to choose, expand, and relate the notion of gender to other categories, thus shedding light on the significance of the margins and the question of otherness. Queerness was to epitomize fluidity in the broadest sense of the word. However, it (the queer) had become yet another contestable category. The diversity of discourses started crossing at different, sometimes paradoxical angles. The attempt to devise gender inclusive language is a demanding task. Norms that regulate linguistic behavior sometimes follow, whereas at times construct social relations. Language of inclusion and respect aims at ensuring human rights, the rule of law, integrity, stability, and prosperity on the level of the individual, society, and region. 
European Parliament insists on gender inclusive language. It discourages the use of generic term of "man," and offers alternatives such as humanity for mankind (Papadimoulis, 2018, p. 10). It suggests avoiding the use of masculine pronouns (he, him) and possessive adjectives (his). The generic use of "they" is perceived as acceptable, but caution is emphasized in cases when it can be offensive. Instead of the titles "Mrs." and "Miss." that indicate marital status, "Ms." is preferred. The document points out the use of some words solely relying on the gender specific/sensitive aspect: "it is still normal to use 'fisherman', 'midwife' " (Papadimoulis, 2018, p. 11). Suggesting the use of "he or she", it warns against stylistic abuse of the option. It discourages deploying "he/she", "him/her", and "s/he", while supporting moderate use of alternating masculine and feminine forms.

According to the United Nations, altering the masculine and feminine pronouns and adjectives is allowed in the whole text. Yet, it is stressed that caution is needed, particularly where it may affect clarity, distort the message, and the meaning. Both organizations recommend using lexical alternatives for the words that can be politically incorrect. The UN suggests using "staff" instead of "manpower". The European Parliament notes that "with increased awareness, such expressions can usually be made gender-neutral" (UN, n.d., p. 7). Both institutions acknowledge domesticated unisex forms "actor" (although there is also the feminine noun "actress"), writer, author, and doctor.

This category includes the gender neutral noun 'teacher'. When it refers to the workers in kindergartens and daycare, it does not do justice to the female demographics who mostly occupy those positions, which mirrors the fact that childcare is to a high degree still the area of domesticity that mainly pertains to women. In Serbian, however, there is a word for a female teacher, the use of which can be a way of addressing the issue. Simic and Simic provocatively tackle the problem by using the Serbian word 'vaspitač' (Simic \& Simic, 2019, p. 149). The article decisively invests in human rights, notably focusing on the gender issue. The authors' use of the masculine gender noun dares one to notice. Showing the obvious can sometimes be a means of calling attention to the marginalized, rendering the invisible detectable. Similar occurrences can be found in the writings of the minds highly engaged in the question of freedom, such as Hannah Arendt's. Arendt uses the gender specific noun 'man'. She is indisputably an emancipated woman and her 
works feature the aspect that discredits a possible uncertainty regarding her stand in the context of human rights.

It is not surprising that gender specific language is being reconsidered and negotiated cautiously nowadays. For transgender, genderqueer, non-binary or third gender individuals whose identity relies on the understanding of gender as a spectrum, rather than a binary, the use of linguistic gender markers may be offensive. The demand for gender neutral language can reflect the investment in the power of discursively constructed realities and the role language plays in engendering social dynamics. On the other hand, the dismissal of the need to provide linguistically articulated acknowledgement of gender specific social situations could be merely a matter of the normativity constitutive of standard language. Both standpoints argue for gender neutral language, however for fundamentally different reasons.

There are diverse aspects of the polemic where human rights collide with linguistic caprice. In other words, we do have the right to our body, to gender, and to choose not to accept the dominant normativity. The question is when and how that right is abused, used for manipulative purposes, and transformed into oppressive political discourse. There are also the points where the distinction between social constructs and social engineering becomes blurry. Put differently, there are instances in the social dynamics that feature misconstrued gender politics. For example, cultural categories, such as gender, that are perceived to be social constructs may be used as a means of obtaining political power. In that scenario, the active participants in the re-description of both the body and body politics may be components in a larger project of social engineering. Similarly, biological determinism strangely intersects with cultural contingency. Those perplexing points are the intersections of the approach that opposes inherent gender identity, simultaneously insisting on the right to the supposed innate gender proclivity to be physically manifested on the body in accordance with the choice. Struggle for power, embodied in language, might become oblivious of the original demands for human rights. These are instances of the collision between finance and ethics.

The public debate regarding the topic has intensified recently, as is evident from discussions on Spiked, a radically leftist magazine uncompromisingly defending freedom of speech and preserving trust in and appreciation of humanity. Pointing out controversial aspects of gender politics, O'Neill exposes sheer hypocrisy under 
the disguise of political correctness. He looks at the media turmoil caused by a disputable case of cultural appropriation related to a model's 'afro hairstyle':

"What we have is a bizarre situation where the woke insist on rigidity in everything to do with race yet demand fluidity in everything to do with sex and gender. They see race as fixed and gender as changeable. This represents the worst of both worlds. Why? Because it discourages something that is actually very positive - cultural and social interaction between different races of people - and it encourages something which really doesn't make much sense or hold much scientific water: the idea that you can change sex simply by declaring it. It frowns upon racial sharing and cheers sexual delusion." (O'Neill, 2018 , October 24)

O'Neill claims that the hairstyle is not cultural appropriation. By so arguing, he warns against over-interpretation of the cultural sphere that may result in divesting cultural exchange of spontaneity, and instead inhibit it with the paranoid perception of the other and self in the key of political correctness. Not only does it disable free speech and is, therefore, a form of (self) censorship, but it also hinders experiencing democracy and diversity in the way that ensures humane perception of and communication with the other.

Similarly, over-medicalization of and a patronizing approach to children may have an obstructive impact on the process of growing up, as O'Neill accentuates in his critique. Those who experience discomfort in relation to sexual aspects of growing up are frequently diagnosed with certain kinds of disorder that pertain to gender problematic. The pathologized, medicalized, and vulnerable beings are allegedly in need of the protection of the state. The culture of victimhood afflicts agency in the intersection of social engineering and biological determinism:

"It feels like children are being experimented on. Both morally and physically. Morally in the sense that they are having every traditional, anchoring view of sex erased from their minds, and physically via drugs and hormone interventions [...] There is no such thing as a trans kid. That is an invention of adult activists, confused parents, and cowardly medical and educational establishments. Let kids be kids. If they're confused, talk to them - just don't diagnose them as messed-up and in need of medical intervention." (O'Neill, 2018, November 22)

O'Neill implicitly addresses the possibility to choose not to question sex assigned at birth, thereby touching upon the very basic 
democratic postulates and imposed dominant normativity. In addition, he infuses in the statement the problem of alienation, particularly in the familial context where communication and authentic relationships are replaced by pharmacological clutches coupled with the state usurping the realm of parenthood. There have been examples of scholarly research about gender politics that was hindered supposedly in the name of gender sensitive issues. The intervention may have a negative impact on the demographics it apparently protects. Caspian presents a dispiriting experience. He intended to conduct research at the Bath Spa University that would focus on the problem of de-transitioning. The university committee rejected his research proposal. Since then, he has been trying to legally reclaim the right to his research. Caspian, who had previously worked for ten years as a psychotherapist with the people who were considering transitioning, points out:

"On the one hand, there is a narrative that gender identity is neurobiological - that you can have such a thing as a female brain in a male baby's body and vice versa. To that end, there are a small number of studies that attempt to show a gendered brain, but there are many others that show that there is not. The other main narrative, in a strange way, is its opposite and yet it runs concurrently. It comes from queer theory [...] But none of these theories have any sound scientific backing or any body of evidence that is generally agreed. They are a series of opinions. The whole field has become entirely political." (Caspian, 2019, February 22)

Caspian explicates the complexity of the situation where gender fluctuates between nature and culture-between the biologically determined aspects of an individual and socially constructed, linguistically enabled choices. The way in which politicization of delicate issues can have dramatic consequences is evident from the observation which is at the same time a kind of warning:

"I was on the board of the psychotherapy regulator when it was being broadened and I was asked to advise on it [...] I wanted to make it safe for therapists, doctors and social workers to work with people who wanted to reverse their transition. Under the terms of the Memorandum, as it stands, they could be struck off their professional register. It would prevent professionals working ethically and safely with anyone who wanted to de-transition." (Caspian, 2019, February 22)

Alongside delivering the message that focuses on the potential for the legally obscured and impaired moral creed in the medical 
profession, Caspian inspires suspicion about the possible corrosive intersection between ethics and finance in the healthcare industry.

Generally, transgender discourse is characterized by the demand for gender neutral language in response to the exclusionary aspects of gender sensitive language. There are cultural contexts that seemingly feature the same views and propose similar demands. They, however, have different points of departure. They apparently insist on linguistic puritanism and oppose the resilience of language and its adaptability to newly arisen situations. Those conservative interventions echo reactionary political currents in the positions of power and political élite. They are based on the top-down imposition of norms. They rely on both the power of their position and the power of language in implementing potentially discriminatory political agenda disguised as a linguistic norm.

One such instance can be found in the heated debate regarding gender sensitive language in the context of the standardization of the Serbian language. In 2017, the Serbian Academy of Sciences and Arts (SASA) revisited the decision they made in 2011 regarding the introduction of feminine nouns signifying certain professions. Serbian feminist academics and non-academics alike-as well as broadly speaking demographics sensitized to the questions of discrimination, otherness, equality, democracy, liberties, and human rights-insist on the appropriate linguistic choice that would reflect the presence of women in society and their empowerment.

The website of SASA-that scholarly, linguistic, and normative authority-features the page updated on May 14, 2018, displaying the announcement of the Institute for the Serbian Language responsible for the standardization of the language (Anonymous, 2018). It is stated that the introduction of lexical versions signifying female individuals carrying out certain jobs is banalization of language. The Committee for the Standardization of the Serbian Language accentuates that the presence of linguistic entities should not be equated with the presence of the actual people. While this seemingly stems from the valid distinction between language and the extralinguistic, it ignores the specificity of the situation and obscures the social significance of such interventions, particularly with regard to the problem of discrimination and democracy by and large.

The document refers to the situation in English and other languages that do not have grammatical gender and, for that reason, 
cannot acknowledge the presence of women in certain roles with a linguistic equivalent that would through grammatical gender reflect natural gender, i.e., the gender and sex of the persons who occupy those positions. SASA puts emphasis on gender neutrality as the viable option. Here, one needs to take into account the other means that the English language offers in order to meet the gender based linguistic requirements and the complexity of the situation it encounters trying to negotiate certain tendencies advocating gender neutral language, as it is evident from the articles presented in this study.

Further insisting on the difference between grammatical and natural gender, they refer to the fact that the existing official grammar reference books ascribe to masculine nouns twofold meaning. For example, man/people, dog, writer, judge, etc. are masculine nouns, and they officially signify persons of both sexes. The use of feminine nouns coined for the purpose of communicating an antidiscrimination message would, therefore, be ungrammatical. In addition, the announcement brings to awareness that sheer introduction of language units does not ensure the politics of inclusion and, vice versa, that absence of gender sensitive language does not necessarily signal the actual discriminatory social situation. It discourages the primacy of political streaks in defining linguistic norms and standards.

Ironically, the Dnevnik (2019) published the mayor of Novi Sad's somewhat patronizing International Women's Day address. He states: "Budućnost je ženskog roda" (Anonymous, 2019, March 7). The English translation would be as provocative: "The gender of the future is female." What makes the situation potentially worrying is that, alternatively, the mayor's sentence can be translated into English as "The gender of the future is feminine." Here, the invisible quotation marks used with the word future may mean that the supposedly hopeful prognostication is a matter of discursive manipulation: Serbian word 'budućnost' is a feminine noun. Consequently, it makes one wonder if in that scenario there is congruence between the world and the word. In either case, the question is whether it is a good thing. Regarding the metalevel, it certainly is: it is good that we provide linguistically accurate accounts of the social. As for the object level, it may be, but is not necessarily so. More precisely, if certain linguistic choices signal gender awareness, and if it resonates with the actual politics of inclusion, than it undoubtfully is indicative of wholesome social relations and their 
accurate linguistic reflections. If language lacks indicators of gender sensitivity, while the society thrives on antidiscrimination politics, we may be cautious and prevent possible confusion. Discourse featuring gender inclusive content that is not congruent with the actual social sphere might not be a preferred option. Confronted with such a complex situation, one wonders whether diversified discourse mirrors atomized society. One may also ask if it spurs the dispersal of the social. By contrast, one would like to know if it perhaps reverberates with and inspires the blossoming of pluralist culture and linguistic playfulness it can ensure.

CONCLUSION Since the days of the suffragettes, who were focused on deeds more than on words, yet who appropriated the term that had been used as a derogatory description of their struggle, humanity has seen many attempts to acknowledge gender rights and to devise suitable linguistic manifestations of social realities. The feminism that coincided with the Civil Rights Movement demanded linguistic expressive modes that would parallel reconfigurations of the public sphere. The next wave of feminism further democratized discourse and gender problematic by channeling the agenda through the language of popular culture and subculture. It expanded into the corporate and virtual realms. Discourse has been oscillating. It has become gender sensitive, and it needs to be rendered gender neutral. One wonders how we can both exercise and discuss antidiscrimination politics, and avoid the bewilderment that the fluctuations of the world-word nexus sometimes cause. Moreover, the question of immense importance is how we can avoid hypocrisy while trying to harmonize discourse and the social sphere. One would like to know how we can generate a sound community of human beings in which language is the means of vibrant communication.

SOURCES MacMillan Dictionary. https://www.macmillandictionary.com

Merriam Webster Dictionary. https://www.merriam-webster.com

Online Etymology Dictionary. https://www.etymonline.com

REFERENCES

Anonymous. (2018). Jezik rodne ravnopravnosti Serbian Academy of Sciences and Arts (SANU). Retrieved from http://www.isj.sanu.ac.rs/2018/05/14/ jezik-rodne-ravnopravnosti 
Anonymous. (2019, March 7). Честитка градоначелника Вучевића поводом Дана жена. Dnevnik. Retrieved from https://www.dnevnik.rs/novi-sad/cestitka-gradonacelnika-vucevica-povodom-dana-zena-07-03-2019

Birns, N. (2010). Theory after theory: An intellectual history of literary theory from1950 to the early twenty-first century. Toronto: Broadview Press.

Broughton, J. (2012). Cultural production. In Nancy Lesko and Susan Talburt (Eds.), Keywords in youth studies (247-251). New York, NY: Routledge. (Original work published in 2011).

Caspian, J. (2019, February 22). My battle with the transgender thought police. Spiked. Retrieved from https://www.spiked-online.com/2019/02/22/ my-battle-with-the-transgender-thoughtpolice

Papadimoulis, D. (2018). Gender neutral language in the European Parliament guidelines. The European Parliament. Retrieved March 15, 2019, from http://www.europarl.europa.eu/cmsdata/151780/GNL_Guidelines_EN.pdf

Glück, R. (2006). The greatness of Kathy Acker. In Amy Scholder, Carla Harryman, and Avital Ronell (Eds.), Lust for life: On the writings of Kathy Acker (45-57). London: Verso.

Hannah, K. (2018) The riot grrrl manifesto. In. Weiss, P. A. Feminist Manifestos: A Global Documentary Reader (330-332). New York: New York University Press.

Hynde, C. (1994). I'm a Mother. [Recorded by the Pretenders]. On The last of the independents [vinyl and CD]. London: The Townhouse Studio and Sarm Studio West; and Bath: The Wool Hall. Retrieved from https://www.lyr ics.com/lyric/1330116/Pretenders/I\%27m+a+Mother

Riot Grrrl. (n.d.). Learning dreamers and dissenters. The British Library. Retrieved June 5, 2019, from https://www.bl.uk/learning/histcitizen/21cc/ counterculture/doityourself/riotgrrrl/riotgrrrl.html

O'Neill, B. (2018, November 22). There is no such thing as a 'trans kid.' Spiked. Retrieved from https://www.spiked-online.com/2018/11/22/there-is-no-s uch-thing-as-a-trans-kid/

O'Neill, B. (2018, October 24). Why isn't transgender 'Cultural Appropriation'?. Spiked. Retrieved from https://www.spiked-online.com/2018/10/24/ why-isnt-transgenderism-cultural-appropriation/

Roberts, F. (n.d.). Pied- à -terre (postcard). Cambridge, UK: Allographic Press.

Simic, M., \& Simic, I. (2019). “Who should care about our children?”: Public childcare policy in Yugoslav socialism and its Serbian aftermath. Journal of family history, 44 (2), 145-158. doi:10.1177/0363199019831402

UN (n.d.). Guidelines for the gender-inclusive language in English. The United Nations. Retrieved March 15, 2019, from http://www.un.org/en/gender-inclusive-language/guidelines.shtml 
TAMAРА М. СТЕФАНОВИК

УНИВЕРЗИТЕТ У ПРИШТИНИ СА ПРИВРЕМЕНИМ СЕДИШТЕМ

У КОСОВСКОЈ МИТРОВИЦИ, ФИЛОЗОФСКИ ФАКУЛТЕТ

ДРАГАНА М. СПАСИЋ

УНИВЕРЗИТЕТ У ПРИШТИНИ СА ПРИВРЕМЕНИМ СЕДИШТЕМ

У КОСОВСКОЈ МИТРОВИЦИ, ФИЛОЗОФСКИ ФАКУЛТЕТ

КАТЕДРА ЗА ЕНГЛЕСКИ ЈЕЗИК И КњИЖЕВНОСТ

РЕЗИМЕ

РОДНО ОСЕТЉИВ И РОДНО НЕУТРАЛАН ЈЕЗИК: ВЕЗА ИЗМЕЂУ ЈЕЗИКА И СВЕТА И ФЛУКТУАЦИЈЕ НА ТОЈ РЕЛАЦИЈИ

Рад истражује однос између језика и света у контексту родне политике нудећи тематски оквир за конструктивну полемику и критичко промишљање, уместо предлога који би требало да имају функцију решења за дату друштвено-политичку ситуацију. Историјска перспектива указује на различите манифестације феминизма и начине на који су оне обликовале језик. Гласови са маргина друштва и даље траже адекватан језик који би био отелотворење антидискриминационе политике и изражавао њихов идентитет. Трансродни активисти се залажу за родно неутралан језик. У исто време, слични захтеви долазе и са другачијих полазишта. Како схватити ту „коинциденцију”? Да ли разноликост дискурса осликава фрагментарност друштва? Да ли то подстиче друштвену разједињеност? Да ли је можда у складу са и пружа подстрек процвату плуралистичке културе и лингвистичке игроликости коју би требало да омогућава?

Суфражеткиње су се бориле за право гласа, право на образовање и рад. Придавале су важност делима више него речима. Међутим, увиделе су и моћ језика и присвојиле назив којим се штампа погрдно изражавала о њима. Тај назив је у употреби и данас у значењу које су му оне дале. Током двадесетог века, покрет за женска права који је добио назив феминизам се омасовио. Фокус се проширио на питања телесног, репродуктивна права, сексуално злостављање, насиље у породици, хетеронормативност, неплаћени рад. У Сједињеним Америчким Државама, Покрет за грађанска права је дао подстрек овом другом таласу феминизма. Започета је борба за преобликовање дискурса тако да одражава новонасталу друштвено-политичку ситуацију.

Трећи талас феминизма (или други, у зависности од класификације) се доводи у везу са покретом Рајат Грл. Феминистичка идеологија се ширила на план поткултура поспешујући подри- 
вање патријархалне доминације. Тај талас је омогућио и присуство жена у менаџерској сфери у већем броју и на позицијама моћи. Четврти талас (или трећи) доводи до оснаживања жена и у дигиталној сфери, што има за резултат јачање свести, моћи деловања и супротстављање друштвеним односима заснованим на дискриминацији.

Промене су нашле своје дискурзивне корелате. Моћ може да се манифестује путем друштвених конструката, контроле и утицаја кроз сферу језика. Перспективе указују на међусобну условљеност на релацији језик-друштво. Разумљиво је што се захтевима за родно неутралан језик приступа са опрезом. За особе чији је избор трансродност, небинарност и трећи род, родно осетљив језик може да буде политички некоректан. Захтев за родно неутралним језиком може да буде последица улоге коју језик има у генерисању друштвених односа. Такође, одбацивање родно осетљивог језика може да се тиче нормативе стандардног језика. Оठа полазишта се залажу за родно неутралан језик, али из посве другачијих разлога.

Поставља се питање како да се спроводи и дискутује дискурс антидискриминационе политике, а да се избегне збрка коју веза између језика и света понекад ствара. Изузетно је значајна могућност да се избегне лицемерје у покушају да се хармонизује дискурс са друштвеном сфером. Питамо се како стварати кохерентну плуралиситичку заједницу људских бића у којој је језик средство сувишне и инспиративне комуникације.

КљУчНЕ РЕчИ: језик; родност; осетљиво; неутрално; политика; антидискриминација; моћ.

Овај чланак је објављен и дистрибуира се под лиценцом Creative Commons Ауторство-Некомерцијално Међународна 4.0 (СC BY-NC 4.0 |

https://creativecommons.org/licenses/by-nc/4.0/).

This paper is published and distributed under the terms and conditions of the Creative Commons Attribution-NonCommercial International 4.0 licence (CC BY-NC 4.0 | https://creativecommons.org/licenses/by-nc/4.0/). 